\title{
Irrigation Depth and Carnauba (Copernicia prunifera) Straw Increase Water Use Efficiency in the Cherry Tomato in a Semi-Arid Region
}

\author{
Janiquelle da Silva Rabelo (Corresponding author) \\ Department of Agronomy / Phytotechnics, Federal University of Ceará \\ Fortaleza Brazil. \\ Tel: +55 (85) 987134426 E-mail: rabelojs@ hotmail.com

\begin{abstract}
Marcelo de Almeida Guimarães
Department of Agronomy / Phytotechnics, Federal University of Ceará Fortaleza Brazil.
\end{abstract}

Tel: +55 (85) 8146-7554 E-mail: mguimara@hotmail.com

\begin{abstract}
Valsergio Barros da Silva
Department of Agricultural Engineering Federal University of Ceará

Fortaleza Brazil.

Tel: +55 (85) 992191607 E-mail: valsergiobarros@ hotmail.com

Raimundo Nonato Távora Costa

Department of Agricultural Engineering Federal University of Ceará Fortaleza Brazil.

Tel: +55 (85) 999841509 E-mail: rabelojs@ hotmail.com
\end{abstract}

Hozano de Souza Lemos Neto

Federal Rural University of the Semi-arid (UFERSA), Science Center Agrarian, Department of Sciences Agronomic and Forestry, Mossoró, RN, Brazil Tel: +55 (85) 999170500 E-mail: hozanoneto@ hotmail.com 


\title{
Rosilene Oliveira Mesquita
}

Department of Agronomy / Phytotechnics, Federal University of Ceará Fortaleza Brazil.

Tel: +55 (85) 9935-3534 E-mail: rosilenemesquita@gmail.com

\author{
Received: Aug. 18, $2020 \quad$ Accepted: Sep. 15, $2020 \quad$ Published: Oct. 22, 2020 \\ doi:10.5296/jas.v8i4.17546 \\ URL: https://doi.org/10.5296/jas.v8i4.17546
}

\begin{abstract}
This research addresses irrigation strategies for saving water, including the use of irrigation depths of 50,75, 100, 125 and $150 \%$ of the crop evapotranspiration (ETc) and a ground cover of carnauba straw, in evaluating the response of the cherry tomato (Solanum lycopersicum var cerasiforme L) submitted to different levels of water availability in soil with and without ground cover, in the semi-arid region of northeastern Brazil. The physiological components showed higher values under ground cover and when submitted to $100 \%$ ETc. The greatest number of total and commercial fruit was obtained when the soil was covered, and irrigated with depths of 75 and $100 \%$. Carnauba straw with irrigation depths of 100 and $125 \%$ resulted in the greatest fresh fruit weight. The highest values for fruit diameter and length were achieved in the soil under cover. Maximum productivity, $11,404.20 \mathrm{~kg} \mathrm{ha}^{-1}$, was obtained at $107.5 \%$, while for the soil with no ground cover, maximum productivity was $7,778.86 \mathrm{~kg} \mathrm{ha}^{-1}$, obtained with an irrigation depth of $140 \%$. Based on the results, soil productivity is possible without a cover of carnauba straw, at an irrigation depth of $50.5 \%$, which can generate savings of $3400 \mathrm{~m}^{3}$ water-cycle $\mathrm{ha}^{-1}$. In addition, water use efficiency in the cherry tomato was $3.06 \mathrm{~kg} \mathrm{~m}^{-3}$ and $1.95 \mathrm{~kg} \mathrm{~m}^{-3}$, with and without ground cover respectively. It can be concluded that the use of carnauba straw makes it possible to reduce water consumption in the 'red' cherry tomato under conditions of water scarcity.
\end{abstract}

Keywords: hydric availability, residue of carnaúba. Solanum lycopersicum var cerasiforme L.

\section{Introduction}

Historically, the tomato (Solanum lycopersicum L.) occupies second position among vegetables in terms of economic importance. In general, the crop enjoys high market demand and this is mainly due to the organoleptic and nutraceutical qualities of the fruit, since it has a high concentration of lycopene (carotenoid with antioxidant action that protects the body against such diseases as intestinal and prostate cancer) (Soares Júnior and Farias, 2012; Perveen et al., 2015; Alvarenga and Coelho, 2013).

Despite the positive aspects of using the tomato for human food, the species requires a lot of water, and when subjected to a water deficiency, production is severely impaired. This is 
because water is essential for promoting plant growth and development, and, when absent, the physiological metabolism is altered causing the flowers to abort and the buds to fall. Excess water is also harmful to the crop since, in addition to causing damage to the fruit such as cracking (Santana et al., 2009), it can also cause anoxic stress (a lack of $\mathrm{O}_{2}$ in the roots), root rot (Taiz et al., 2017), nutrient leaching (Lima et al., 2012) and greater infection by disease (Café-filho et al., 2019a). In addition, when environmental or seasonal conditions are conducive to any particular disease, irrigation can be a determining factor in its development against the tomato (Café filho et al., 2019b).

Irrigation water is becoming a limited resource in arid and semi-arid regions. Therefore, controlling the water supply should be considered high priority (Mattar et al., 2020; Pék et al., 2014). One of the alternatives for increasing water use efficiency in agriculture is through the adoption of irrigation systems that use little water in the soil; this also contributes to maintaining its aggregate structure, avoiding the risk of degradation and salinization (Wang et al., 2011a).

In addition to the use of more localized irrigation methods, such as micro-sprinklers and drips, one other alternative is the use of ground cover. This method, in addition to preserving and improving the quality of the soil in the long term, also serves as a barrier, preventing evaporation of the water, reducing the speed of surface runoff and, as a result, allowing greater infiltration in the soil, reducing infestation by invasive plants, and enabling greater temperature stability in the soil surface layers (Mulumba and Lal, 2008; Plaza-Bonilla et al., 2015).

Despite the issues described above, studies on the physiology of vegetables grown in different water regimes under the climate conditions of the semi-arid region are limited. Such a situation makes this study fundamental, as it can help, not only to improve water use efficiency in agriculture, but mainly because it allows the cultivated area to be increased without necessarily requiring greater water availability.

The aim of this work, therefore, was to evaluate the physiological and productive effects of the application of different irrigation depths, with and without ground cover, on cultivating cherry tomatoes in the semi-arid region of the Northeast.

\section{Material and Methods}

\subsection{Experimental Area}

The experiment was carried out in the field from June 2016 to January 2017. The experimental area is located in the Vale do Curu, district of Pentecoste, in the state of Ceará. During the experimental period, the mean daily maximum and minimum temperatures in the area were 38.6 and $23.5^{\circ} \mathrm{C}$ respectively. The mean relative humidity as $58.5 \%$ and the mean daily reference evaporation, $6.21 \mathrm{~mm}$. The mean annual rainfall is $797.0 \mathrm{~mm}$, with the rainfall distribution considered to be irregular. According to Köppen, the climate is type BSw'h', hot semi-arid.

For the experiment, water from a shallow well, $10.0 \mathrm{~m}$ in depth and $5.0 \mathrm{~m}$ in diameter, was 
used. The quality characteristics of the water used for irrigation were pH: 6.90, EC: $1.46 \mathrm{dS}$ $\mathrm{m}^{-1}$, SAR: $1.23, \mathrm{Ca}^{2+:} 4.80$ mmolc $\mathrm{L}^{-1}$ and $\mathrm{Mg}^{2+:} 5.80$ mmolc $\mathrm{L}^{-1}$. The water was classified as type C3S1.

Based on the results of the water analysis, it can be seen that the electrical conductivity showed an acceptable value for salinity in terms of tolerance for the tomato crop, since, according to Alian et al. (2000), the maximum salinity of the soil saturation extract tolerated by the crop is $2.5 \mathrm{dS} \mathrm{m}^{-1}$, classifying the crop as moderately sensitive (Maas and Hoffman, 1977). According to Cordeiro (2001), the $\mathrm{pH}$ levels were considered normal.

\subsection{Experimental Design}

The design used was of randomized blocks arranged in subdivided plots, with three replications per treatment. The plots consisted of the irrigation depths, with 50, 75, 100, 125 and $150 \%$ of the crop evapotranspiration (ETc), estimated based on the evaporation from a Class A pan located five meters from the experimental area. The measurements were obtained daily, and the crop water requirement was calculated from the evaporation of the previous day. The subplots consisted of the carnauba straw and the soil with no ground cover.

Each plot had a total area of $28 \mathrm{~m}^{2}$. The subplots were $7 \mathrm{~m}^{2}$ each, and comprised 12 plants at a spacing of $0.5 \mathrm{~m}$ between plants and $1.0 \mathrm{~m}$ between rows. The tomatoes were grown on two stems, each with eight clusters. The plants were trained vertically using polyethylene tape 15 days after transplanting.

\subsection{Plant Growth}

The cherry tomato seedlings, distributor Top Seed, were produced in polyethylene trays of 162 cells, with a volume of $31 \mathrm{~cm}^{3}$ per cell, filled with substrate containing $90 \%$ earthworm humus and $10 \%$ vermiculite. After sowing, the trays were placed in a shelter under $50 \%$ shade where they remained until 25 days after sowing (DAS), i.e. when they had 3 to 4 definitive leaves. They were then transplanted to the field.

The chemical and physical characteristics of the soil were P: $6 \mathrm{mg} \mathrm{Kg}{ }^{-1}, \mathrm{~K}^{+}: 0.29$ cmolc $\mathrm{Kg}^{-1}$, $\mathrm{Ca}^{2+:} 3.0$ cmolc $\mathrm{Kg}^{-1}, \mathrm{Mg}^{2+}: 1.5$ cmolc $\mathrm{Kg}^{-1}, \mathrm{Fe}: 18.8 \mathrm{mg} \mathrm{Kg}{ }^{-1}, \mathrm{Cu}: 0.8 \mathrm{mg} \mathrm{Kg}{ }^{-1}, \mathrm{Zn}: 0.4 \mathrm{mg}$ $\mathrm{Kg}^{-1}, \mathrm{Mn}: 30.8 \mathrm{mg} \mathrm{Kg}{ }^{-1}, \mathrm{Al}^{3+}$ : 0.15 cmolc $\mathrm{Kg}^{-1}, \mathrm{Na}^{+}: 0.05$ cmolc $\mathrm{Kg}^{-1}, \mathrm{H}^{+} \mathrm{Al}^{3+}$ : 0.16 cmolc $\mathrm{Kg}^{-1}$, SB: 4.80 cmolc Kg-1 $\mathrm{CEC}(\mathrm{T}): 7.3 \mathrm{~g} \mathrm{Kg}^{-1}, \mathrm{OM}: 9.62 \mathrm{~g} \mathrm{Kg}^{-1}, \mathrm{C}: 5.58 \mathrm{~g} \mathrm{Kg}^{-1}, \mathrm{~N}: 0.52 \mathrm{~g}$ $\mathrm{Kg}^{-1}$, C/N: 11, pH: 5.9, V: 66\%, m: 3\%, Clay: $79 \mathrm{~g} \mathrm{Kg}^{-1}$, EC: $0.16 \mathrm{dS} \mathrm{m}{ }^{-1}$, Natural clay: $59 \mathrm{~g}$ $\mathrm{Kg}^{-1}$, Coarse sand: $551 \mathrm{~g} \mathrm{Kg}^{-1}$, Fine sand: $229 \mathrm{~g} \mathrm{Kg}^{-1}$, Silt: $141 \mathrm{~g} \mathrm{Kg}^{-1}$. The soil had a sandy loam texture.

\subsection{Application of the Irrigation Depths}

The ETo was calculated from the evaporation of a Class A pan (Eca) multiplied by the pan coefficient (kp) (Equation 1).

$$
\mathrm{ETo}=\text { Eca } \mathrm{x} \mathrm{Kp}
$$

where: 
Eca - Evaporation of a Class A pan, in mm;

Kp - Pan coefficient.

The crop evapotranspiration is equal to reference evapotranspiration (ETo) multiplied by the tomato crop coefficient at each stage of development $(\mathrm{Kc})$, stage 1: initial - 0.4 to 0.5 , stage 2 : vegetative -0.7 to 0.8 , stage 3 : flowering -1.05 to 1.25 , stage 4 : fruiting - 0.8 to 0.9 , stage 5 : maturation - 0.6 to 0.65 (Doorenbos; Kassan, 1994); as per equation 2.

$$
\mathrm{ETc}=\mathrm{ETo} \mathrm{x} \mathrm{Kc}
$$

where:

ETo - Reference evapotranspiration, in $\mathrm{mm} \mathrm{day}^{-1}$;

ETc - Potential crop evapotranspiration, in $\mathrm{mm} \mathrm{day}^{-1}$;

Kc - Crop Coefficient.

The irrigation required to replace the total volume of water lost through evapotranspiration (ETc) was applied in two instalments per day. As the irrigation system was localized, the ETc was corrected relative to the percentage wet area (PWA), resulting in the localized crop evapotranspiration (ETcloc) (Bernardo et al., 2009). Equation 3 was used to calculate the percentage wet area.

$$
\mathrm{PWA}=\mathrm{NEP} \frac{\mathrm{Se}-\mathrm{w}}{(\mathrm{Sp}-\mathrm{Sr})}-100
$$

where:

PWA - Percentage wet area, in (\%);

Se - Spacing between emitters, in m;

Sp - Spacing between plants, in $\mathrm{m}$;

$\mathrm{Sr}$ - Spacing between rows, in $\mathrm{m}$;

$\mathrm{W}$ - Maximum wet-bulb diameter per emitter, in $\mathrm{m}^{2}$;

NEP - Number of emitters per plant.

The crop evapotranspiration for localized irrigation was obtained with Equation 4 (Bernardo et al., 2009).

$$
\text { ETcloc }=\text { ETc. } 0,1 . \sqrt{ } \text { PAM }
$$

where:

ETcloc - Localized crop evaporation, in $\mathrm{mm} \mathrm{day}^{-1}$;

Irrigation time was calculated based on the ETcloc, the dripper flow and the wet area (Equation 5). 


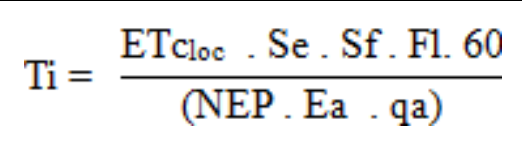

where:

Ti - Irrigation time, in min;

Fd - Percentage irrigation depth defined by the treatment, in (\%);

Ea - Application efficiency, in (\%);

$\mathrm{Se}$ - Spacing between emitters, in $\mathrm{m}$;

$\mathrm{Sr}$ - Spacing between rows, in $\mathrm{m}$;

Qa - Mean dripper flow, in L. $\mathrm{h}^{-1}$.

For the first 11 days after transplanting, each treatment received the irrigation depth required by the crop, to guarantee the uniform development of the plants until becoming established.

The different irrigation managements were started on the $12^{\circ}$ (DAT - day after transplanting. A drip irrigation system was used, with Katif self-compensating button emitters installed in $16 \mathrm{~mm}$ polyethylene tubes at a spacing of $0.50 \mathrm{~m}$, with a flow rate of $3.8 \mathrm{~L} \mathrm{~h}^{-1}$ and a working pressure of 20 mca. Irrigation was controlled by valves, with one in each plot.

\subsection{Gas Exchange}

Ninety days after sowing (DAS), the physiological aspects of the plants were evaluated with the LI6400XT® (LI-COR) infrared gas analyzer (IRGA). The third pair of fully developed leaves was used in the analysis.

The following physiological characteristics were evaluated: a) Stomatal conductance ( $g s$ $\left.\mu \mathrm{mol} \mathrm{H}_{2} \mathrm{O} \mathrm{m}^{-2} \mathrm{~s}^{-1}\right)$, b) Rate of leaf transpiration $\left(E-\mathrm{mmol} \mathrm{H}_{2} \mathrm{O} \mathrm{m}^{-2} \mathrm{~s}^{-1}\right)$, c) Net photosynthetic rate $\left(A-\mu \mathrm{mol} \mathrm{CO}_{2} \mathrm{~m}^{-2} \mathrm{~s}^{-1}\right)$; d) Instantaneous water use efficiency $(A / E)$; e) Internal carbon dioxide concentration $\left(\mathrm{Ci}-\mu \mathrm{mol} \mathrm{CO} 2 \mathrm{~mol}^{-1}\right)$; f) Leaf temperature $\left({ }^{\circ} \mathrm{C}\right)$; g) Ratio between the internal and environmental carbon dioxide concentration $(\mathrm{Ci} / \mathrm{Ca})$ and $\mathrm{h})$ Instantaneous carboxylation efficiency $(\mathrm{A} / \mathrm{C} \mathrm{i})$.

\subsection{Morphological Characteristics}

The fruit were harvested when they were 'cane green' in color, starting at 75 DAS when the following data were collected per plant for each treatment: 1) Total number of fruit, 2) Number of commercial fruit, 3) Number of non-commercial fruit, 4) Total fruit weight (g plant $\left.\left.^{-1}\right), 5\right)$ Commercial fruit weight $\left.\left(\mathrm{g} \mathrm{plant}^{-1}\right), 6\right)$ Non-commercial fruit weight $\left.\left(\mathrm{g} \mathrm{plant}^{-1}\right), 7\right)$ Fruit length (FL, mm), 8) Fruit diameter (FD, mm) and 9) Productivity (PROD, t ha ${ }^{-1}$ ).

\subsection{Water Use Efficiency}

The water use efficiency was determined from the ratio between the values for total fruit biomass and the amount of water applied $(\mathrm{mm})$ in each treatment during cultivation, as per equation 6: 


$$
\mathrm{WUE}=\frac{\mathrm{Y}}{(\mathrm{W})}
$$

where:

WUE - Water use efficiency, in $\mathrm{kg} \mathrm{ha}^{-1} \mathrm{~mm}^{-1}$;

$\mathrm{Y}$ - Crop yield, in $\mathrm{kg} \mathrm{ha}^{-1}$;

W - Total irrigation depth applied during the crop cycle, in $\mathrm{mm}$.

\subsection{Statistical Analysis}

Plant development data were submitted to analysis of variance by F-test, with the mean values compared by the Scott-Knott test $(\mathrm{p}>0.05)$ using the Sisvar statistical software (Ferreira, 2011). The physiological characteristics were analyzed graphically by regression analysis, and trend curves were prepared using the SigmaPlot 11.0 and TableCurve 2D v5.01 statistical software.

\section{Results and Discussion}

Daily evapotranspiration in the cherry tomato varied from 0.73 to $6.0 \mathrm{~mm} \mathrm{day}^{-1}$ during the experimental period. A drop in the ETcloc was seen at the end of the crop cycle, probably influenced by the increase in cloud cover.

The values for localized evapotranspiration (ETcloc) were lower than those of the reference evapotranspiration (ETo), this difference being influenced by the wet-area correction (PWA), as well as by the crop coefficient (Kc), as shown in Figure 1.

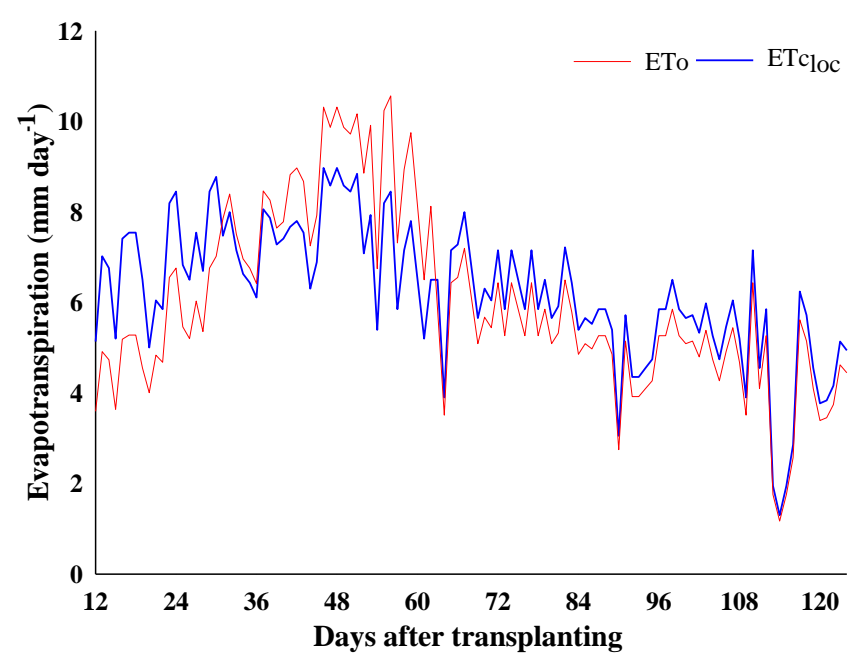

Fig. 1. Reference evapotranspiration (ETo) and localized crop evapotranspiration (ETcloc) during the experimental period

\subsection{Accumulated Irrigation Depth}

The results show the application of $12.05 \mathrm{~L} \mathrm{plant}^{-1}$ at 11 days, before the start of the different irrigation levels and after the application of 105.5, 158.25, 211.00, 263.75 and $316.50 \mathrm{~L}$ 


\section{Macrothink}

Journal of Agricultural Studies

ISSN 2166-0379 2020, Vol. 8, No. 4

plant $^{-1}$ cycle $^{-1}$, corresponding to $211,316.5,422.0,527.5$ and $633.0 \mathrm{~mm} \mathrm{cycle}^{-1}$, for an ETcloc replacement rate of 50, 75, 100, 125 and 150\% respectively (Figure 2), which is consistent with previous research (Pék et al., 2015).

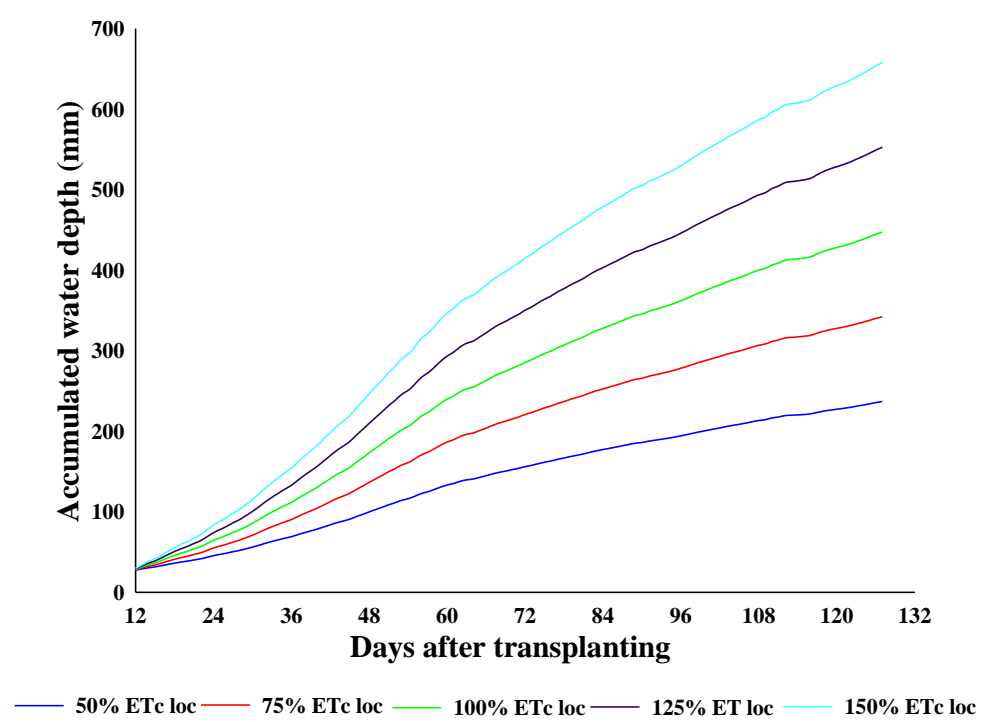

Fig. 2. Accumulated irrigation depth for management at levels of 50, 75, 100, 125 and 150\% ETcloc

Several studies have shown different depths being applied to the tomato (Monte et al., 2009; Macêdo; Alvarenga, 2005; Doorenbos and Kassan, 1994; Café-Filho et al., 2019b). The differences seen between these studies are mainly related to the climate conditions of the location (Schwarz et al., 2013), and may also have been influenced by the variety and/or cultivar used in the research (Albuquerque Neto et al., 2012).

According to the researchers, the mean relative humidity at the experimental site was $58.5 \%$ and the maximum and minimum temperatures were 37.2 and $28.5^{\circ} \mathrm{C}$ respectively, different from the ideal temperatures reported by some researchers (Goto and Tivelli, 1998 ) for the tomato at different stages of crop development (Figure 3). 


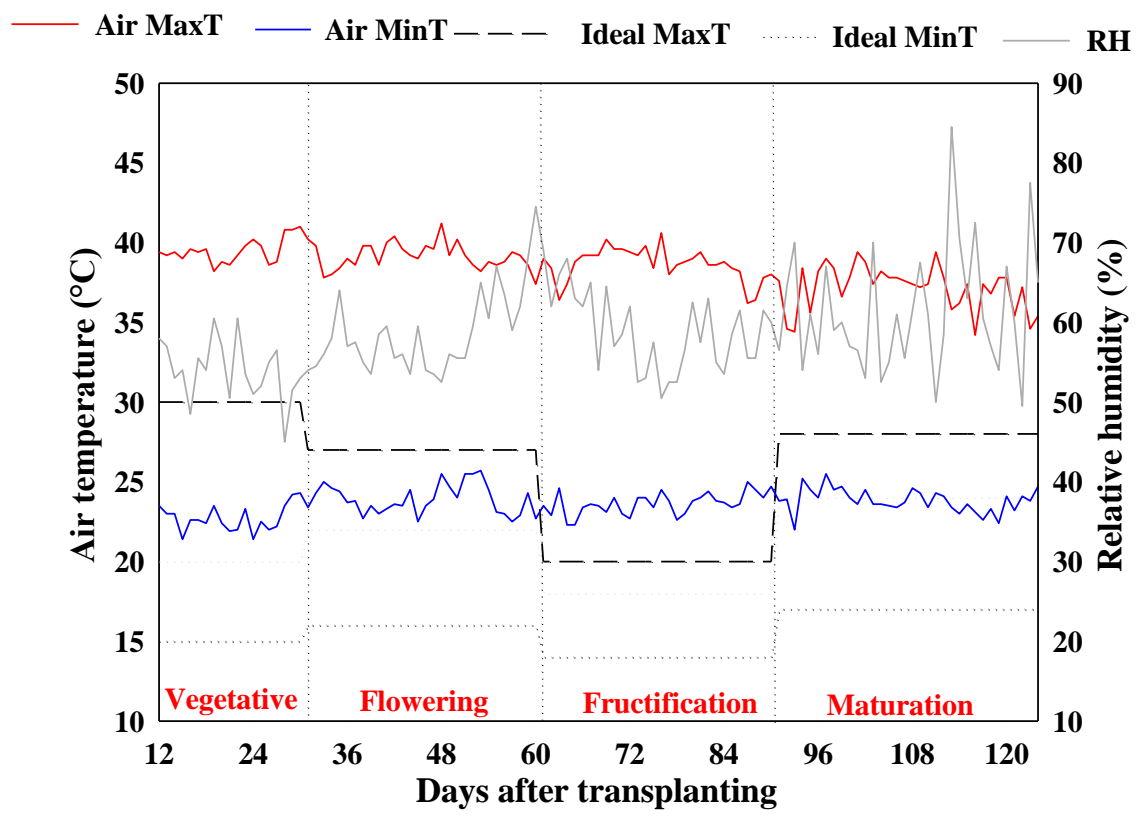

Fig. 3. Maximum (Tmax) and minimum (Tmin) temperature in ${ }^{\circ} \mathrm{C}$ and relative air humidity (RH), from September 2016 to January 2017

According to Goto and Tivelli (1998), the optimal temperature for the tomato varies depending on the stage of development: during the vegetative stage, from 20 to $30^{\circ} \mathrm{C}$; during pollen formation, from 20 to $26^{\circ} \mathrm{C}$; during growth of the pollen tube, from 22 to $27^{\circ} \mathrm{C}$; during fruit setting, from 18 to $20^{\circ} \mathrm{C}$, and during ripening, from 24 to $28^{\circ} \mathrm{C}$. According to Taiz et al. (2017), the lethal temperature for the tomato is $45^{\circ} \mathrm{C}$.

However, even at this temperature, with abundant access to water, most plants are able to keep the temperature of the leaves below this limit, using a defence mechanism known as evaporative cooling, including environments with high temperatures.

Evaluating the morphological characteristics of the 'red' cherry tomatoes, it was found that the different water levels applied to soil covered with carnauba straw and to soil with no cover resulted in variations in the production and quality characteristics of the harvested fruit (Figure 4). 

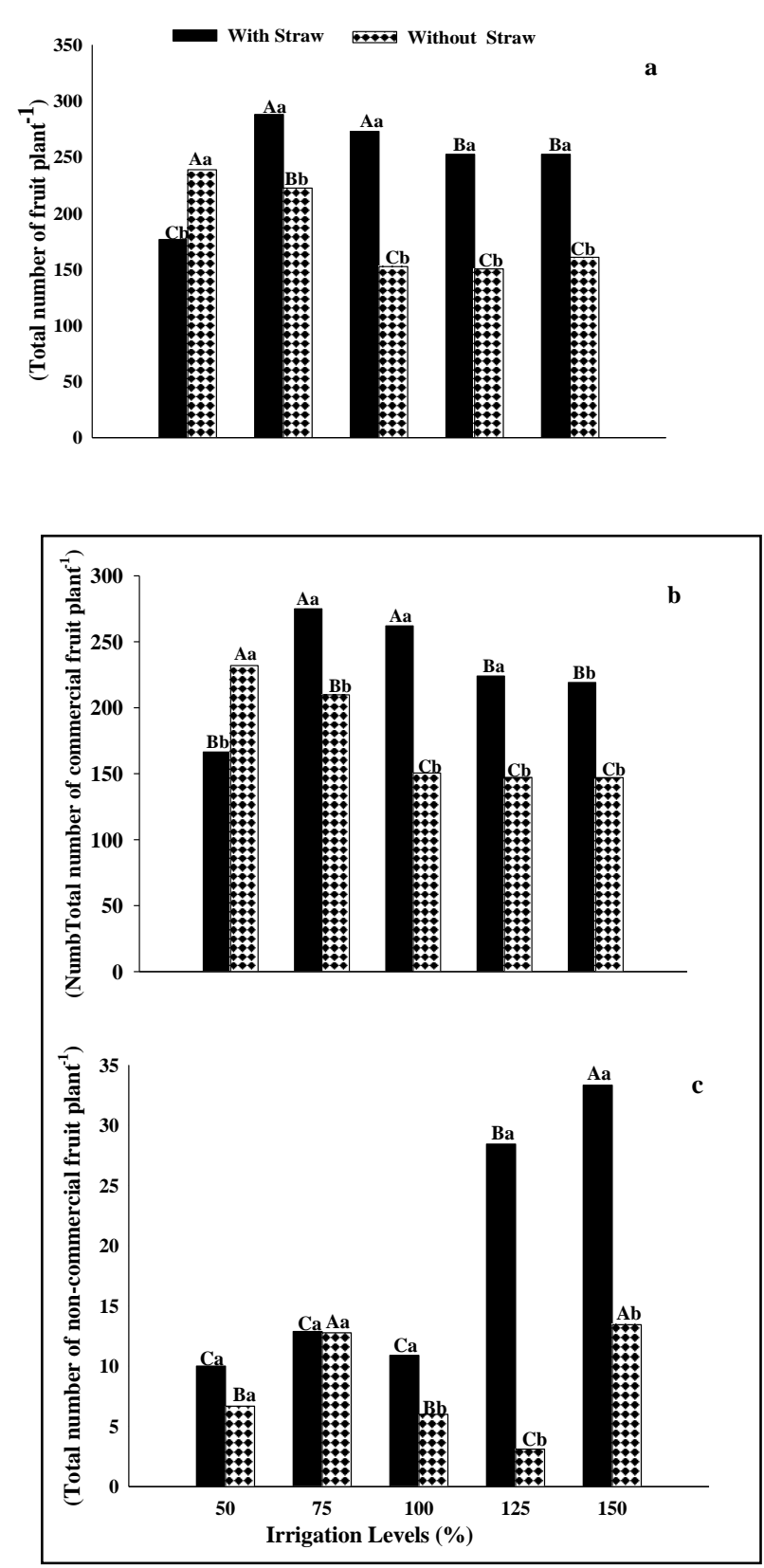

Fig. 4. Number of total (a), commercial (b) and non-commercial (c) fruit in the 'red' cherry tomato. Uppercase letters compare water conditions for the same type of cover. Lowercase

letters compare water levels between the two types of cover. Mean values followed by uppercase letters on a row and lowercase letters in a column do not differ by Scott-Knott test

$$
(\mathrm{p}>0.05)
$$

The greatest number of fruit was obtained when the soil was covered with carnauba straw; the plants submitted to depths of 75 and $100 \%$ ETcloc produced the greatest number of total (Figure 4a) and commercial fruit (Figure 4b), while the plants submitted to $150 \%$ ETcloc produced the greatest number of non-commercial fruit (Figure 4c).

The larger amount of non-commercial fruit resulting from the application of $150 \%$ ETcloc may be related to an excess of water in the soil, which was probably the main reason for the 


\section{Macrothink

appearance of cracked fruit, and a result of the strength of the established source-drain ratio (Taiz et al., 2017) as well as the low elasticity of the cell walls that comprise the fruit epidermis.

The results obtained in this study were superior to those obtained by Silva et al. (2011), who evaluated 11 strains of cherry tomatoes, harvesting an average of 148.92 fruits plant ${ }^{-1}$.

For the total fresh (Figure 5a) and commercial weight of the tomato fruit (Figure 5B), the soil with ground cover, submitted to irrigation levels of between 50 and $125 \%$ ETcloc, afforded better conditions for obtaining greater fruit weight compared to the soil with no cover. The highest values obtained for these characteristics occurred in covered soil and with the application of 100\% of the crop ETcloc (Figure 5).

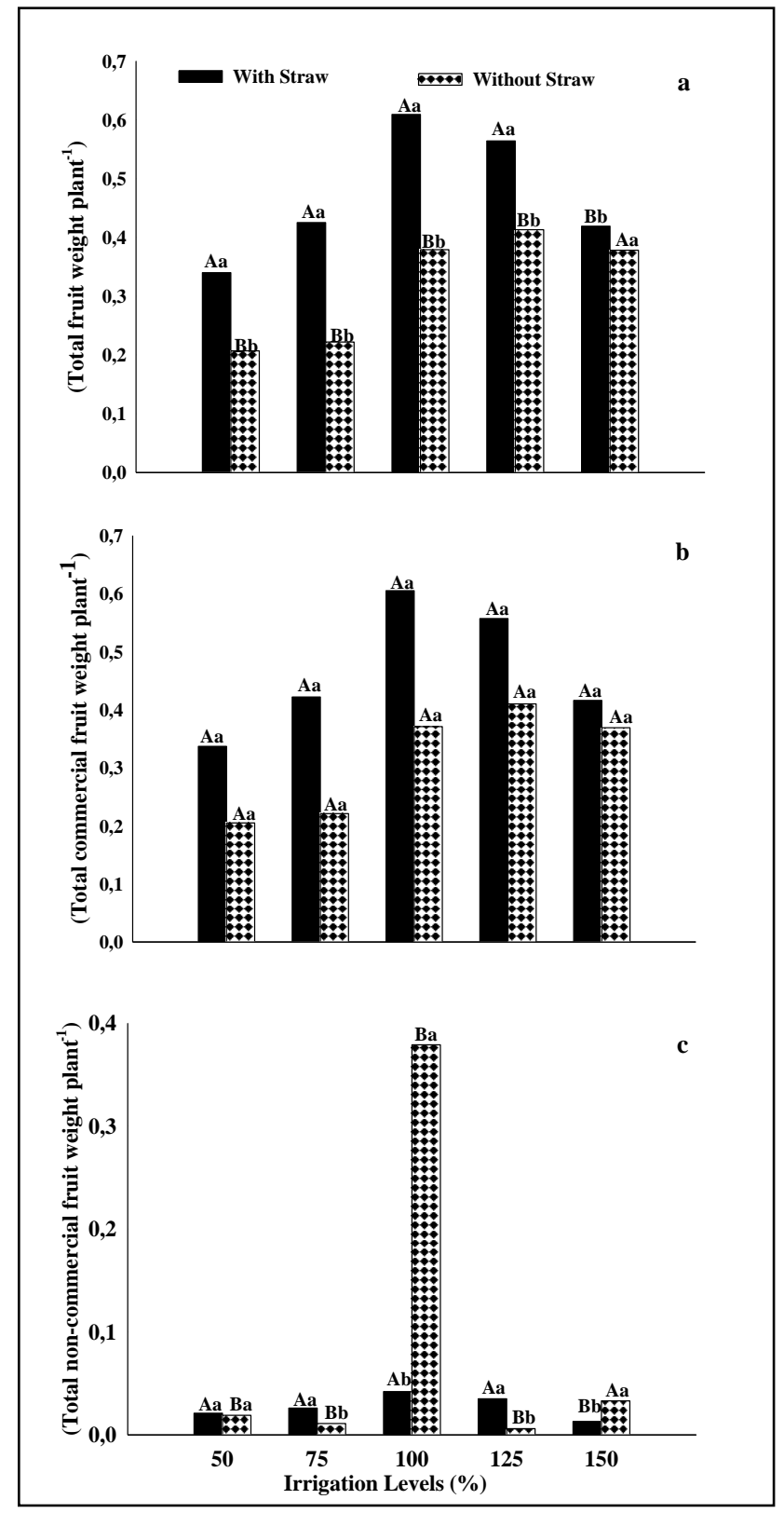




\section{Ml Macrothink}

Fig. 5. Total, commercial and non-commercial fresh fruit weight in the 'red' cherry tomato.

Uppercase letters compare water conditions for the same type of cover. Lowercase letters cover. Mean values followed by uppercase letters on a row and lowercase letters in a column do not differ by Scott-Knott test $(\mathrm{p}>0.05)$

The soil with ground cover, submitted to irrigation levels between 50 to $125 \%$ ETcloc, resulted in the greatest fresh weight production of non-commercial fruit (Figure 5c). For the plants grown in covered soil and submitted to $150 \%$ ETcloc, the lower value for non-commercial fresh weight is due to most of the fruit being cracked, causing a loss of moisture to the environment, and resulting in a lower weight for this treatment.

Despite the number of total and commercial fruit at the irrigation depth of $50 \%$ being higher for the soil with no cover, they were not greater for total or commercial fresh weight. A similar result was found by Abdel-Razzak et al. (2016) and Abdel-Razzak et al. (2013), where the weight, size and total yield of the cherry tomato fruit decreased as the amount of water applied was reduced under the treatment with water stress $(50 \% \mathrm{ETc})$.

This lower production may be related to the greater number of inflorescences seen in the plants under this treatment compared to those grown under other treatments. The large number of flowers produced can influence the production of photoassimilates (Picanço et al., 1998), which may be insufficient, thereby not meeting the demand of the plants during the flowering and fruiting stages, causing the flowers to abort.

Controlling the number of flowers, fruit and stems reduces competition for photoassimilates by the drainage organs, especially the fruit. This practice tends to lead to larger fruit (Beckles, 2012), mainly due to the reduction in competition by the drains (flowers and fruits) for the photoassimilates produced by the sources (leaves).

For the characteristics of diameter (Figure 6a) and length (Figure 6b) in the cherry tomato fruit, a difference was also seen between plants grown under the different irrigation depths, both with and without ground cover. The mean values for diameter varied from $11.59 \mathrm{~mm}$ to $21.65 \mathrm{~mm}$ for soil with and without cover at water depths of between 50 and $150 \%$ ETcloc.

In general, the greatest values for diameter and length were obtained with the plants grown in soil with ground cover, especially at the irrigation depth of $150 \%$ ETc, since the largest fruit diameters were seen for this combination. 


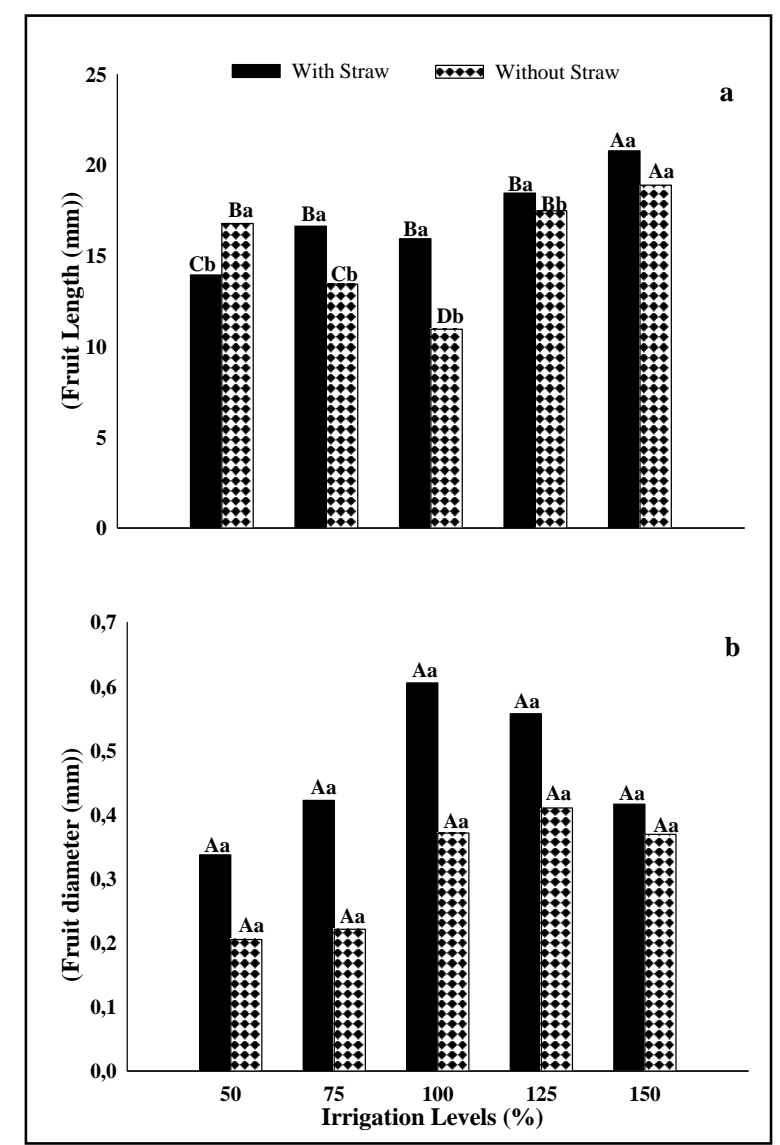

Fig. 6. Fruit length (a) and Diameter (b) in the 'red' cherry tomato. Uppercase letters compare water conditions for the same type of cover. Lowercase letters compare water levels between the two types of cover. Mean values followed by uppercase letters on a row and lowercase letters in a column do not differ by Scott-Knott test ( $\mathrm{p}>0.05)$.

The length and diameter of the fruit are affected by turgor pressure (Silva et al., 2013), i.e. the pressure exerted by water on the membranes and cell walls of the fruit. Water stress caused by the lack of water reduces the potential for cell wall expansion, with the fruit remaining small compared to fruit produced with a greater supply of water.

Taiz et al. (2017) cite a reduction in the rate of cell division and elongation as recurrent in plants submitted to environments under water stress. Loos et al. (2009) mention a drop in the quality of tomato fruit produced under similar conditions.

The above statements were confirmed in this study, since when water availability was from 50 to $150 \%$ ETcloc, an increase was seen of 57.22 and $49.10 \%$ in the diameter and length of the fruit respectively. These results agree with those obtained by Abdel-Razzak et al. (2016), according to whom, as the level of water supplied to the plants is increased, the weight and mean size of the fruit increases.

For the physiological characteristics evaluated 90 days after sowing, the plants grown with ground cover and those grown with no cover showed different responses. In general, the highest values were usually found in plants grown in soil covered with carnauba straw, with 
quadratic adjustments seen for each curve generated, regardless of the use of ground cover (Figure 7).
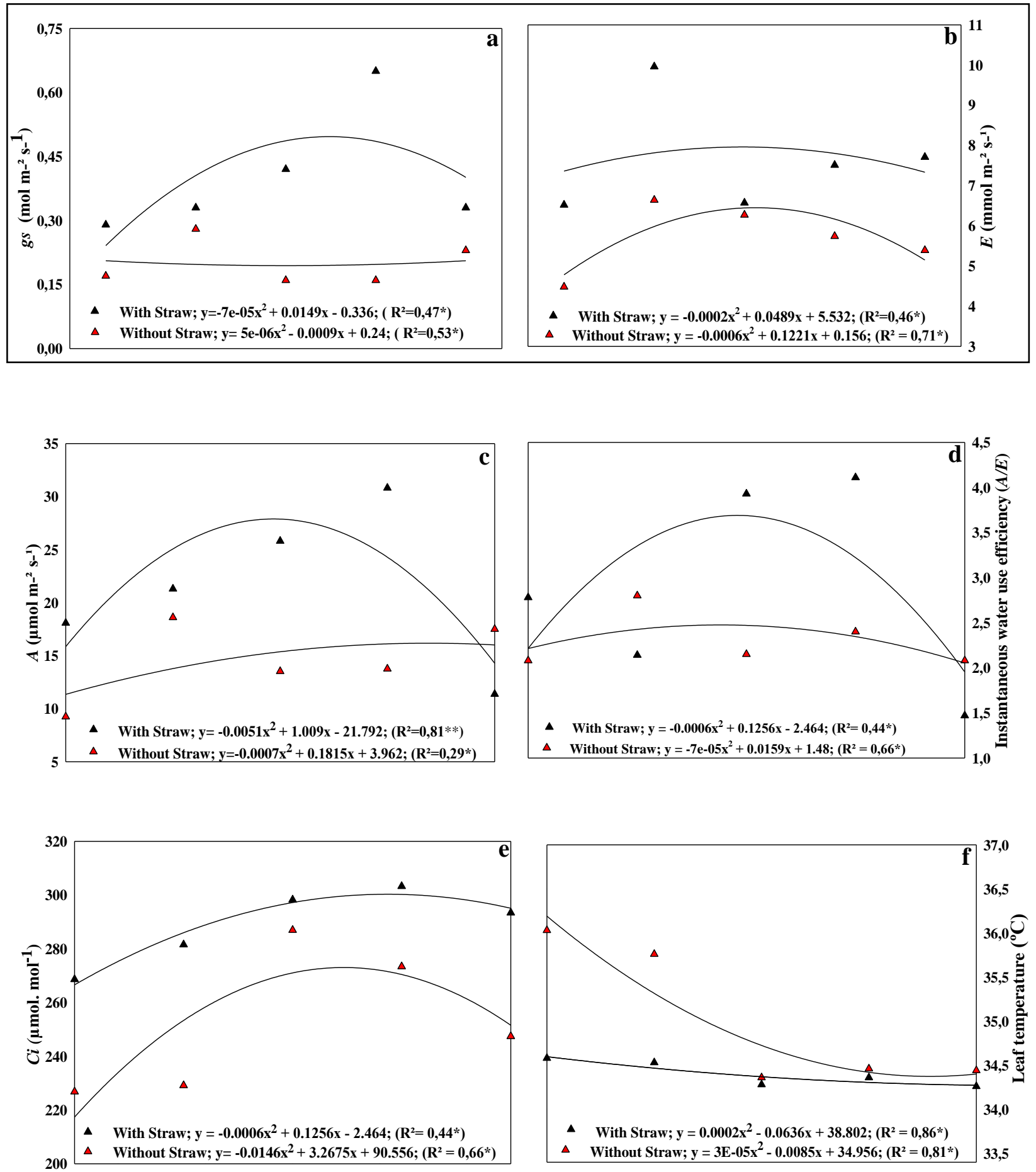


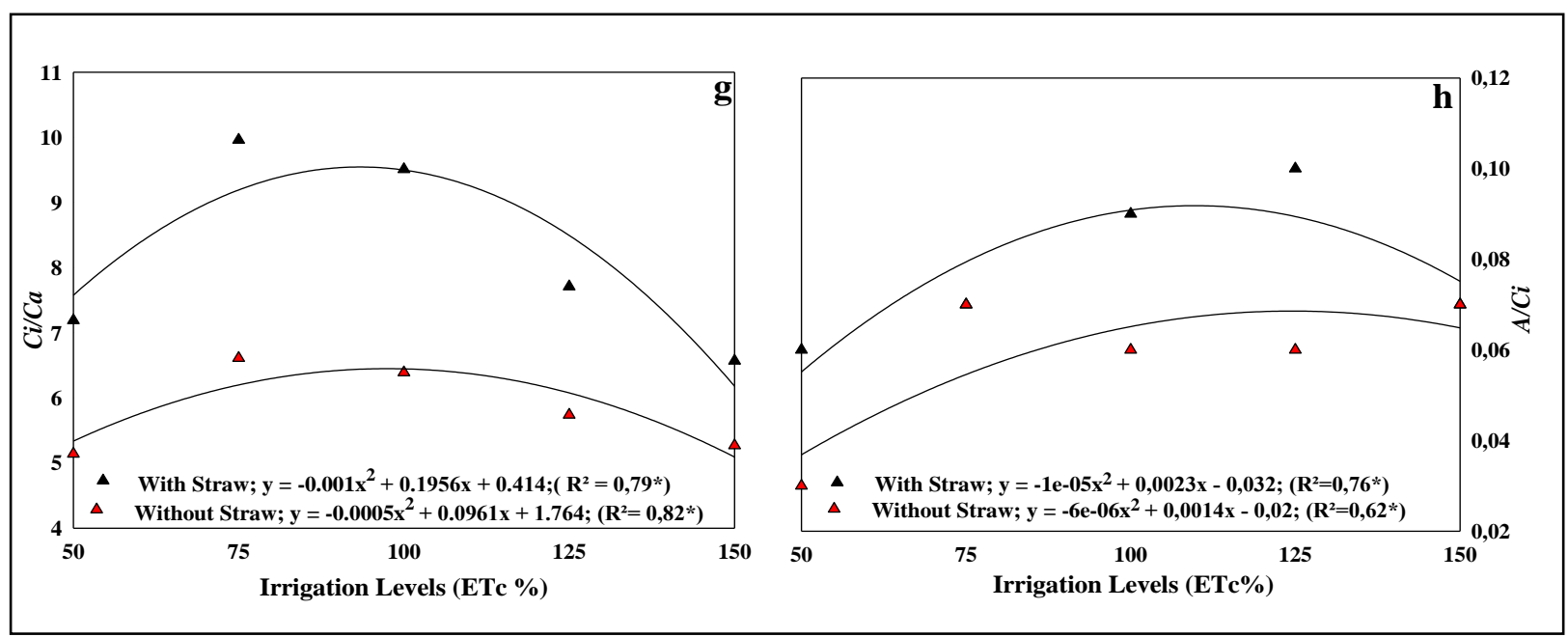

Fig. 7. Gas exchange in the 'red' cherry tomato grown in soil with ground cover (Carnauba straw) and with no ground cover 90 days after sowing, with both submitted to different levels of irrigation.

The maximum value seen for stomatal conductance (gs) was $0.46 \mathrm{~mol} \mathrm{~m}^{-2} \mathrm{~s}^{-1}$, while in the soil with no ground cover, the maximum conductance was $0.22 \mathrm{~mol} \mathrm{~m}^{-2} \mathrm{~s}^{-1}$. It can be seen in Figure $7 \mathrm{a}$ that the use of cover resulted in the cherry tomato always showing higher values than when grown in soil with no cover.

The results for stomatal conductance reflect the positive effect of using a ground cover of carnauba straw compared to the soil with no cover. This is because the use of cover results in soil moisture being maintained over time, with the water in the soil available to the plants for a longer period.

Water being available to the plants for a longer period favours the maintenance of stomatal opening, with a direct influence on conductance, which increases (Taiz et al., 2017). This corroborates Lima et al. (2009), who cite the use of mulch as retarding water deficiency.

Similar behaviour to that of stomatal conductance was seen for transpiration rate (Figure 7B) and photosynthesis (Figure 7C), confirming the assumption that soil covered with straw is more efficient at keeping moisture, and becomes more efficient over time, allowing greater opening of the stomata, through which water loss (transpiration) and the entry of carbon dioxide for photosynthesis takes place.

According to Manzoni et al. (2013), transpiration depends on the amount of water in the soil, as well as the density and depth of the root area.

The physiological factors are all interconnected and reflect decisively on each other. The reduction in the hydraulic conductivity of the soil probably limited the amount of water available to the plants, which reduced stomatal conductance, thereby affecting transpiration and photosynthesis (Manzoni et al., 2013).

Monitoring gas exchange through stomatal closure is considered a difficult process, as plants 
have to 'choose' between reducing $\mathrm{CO}_{2}$ assimilation by closing the stomata, or losing water by opening them, both of which are detrimental to plant development; the plant, however, generally tends to favour the photosynthetic rate (Pereira et al., 2012).

Water use efficiency, evaluated by the relationship between the net photosynthesis of the plant and its rate of transpiration, related to the amount of water lost by the plant and the amount of carbon that the plant is able to fix (Taiz et al., 2017), was superior in plants grown with ground cover (Figure 7d), since these were more efficient in instantaneous water use compared to those grown in soil with no cover. However, a reduction was seen when irrigation depths greater than $104.7 \%$ ETcloc were applied to tomato plants grown with ground cover.

This may be related to a possible excess of water in the root system that could be reducing the availability of $\mathrm{O}_{2}$ necessary for energy production and cell multiplication, among other recurrent physiological processes in the root system. This reduction in oxygen availability induces stomatal closure (Mesquita et al., 2013), apparently without detectable changes in the water potential of the leaf.

A decrease in oxygen availability to the roots has a similar result in the plant as a water deficit, since both can stimulate the production of abscisic acid (ABA) and its being directed to the leaves (Taiz et al., 2017).

Unlike in this study, Marouelli et al. (2003) and Sá et al. (2005) found a linear increase in water use efficiency when the tomato was submitted to increasing levels of soil water tension. In the soil with no ground cover, the plants grown under a water availability of $113.6 \%$, achieved greater maximum efficiency in instantaneous water use, with a WUEi value of 2.38, corresponding to $58.04 \%$ less than the soil with ground cover.

Regarding the internal $\mathrm{CO}_{2}$ concentration in the substomatal chamber, and its ratio to the atmospheric $\mathrm{CO}_{2}$ concentration and instantaneous carboxylation efficiency, the cherry tomato plants grown with ground cover (Figure $7 \mathrm{e}$, Figure $7 \mathrm{~g}$ and Figure $7 \mathrm{~h}$ respectively), showed similar behaviour, compatible with the other physiological characteristics already studied, this being directly related to stomatal conductance and photosynthesis. The greater the stomatal opening, the greater the tendency for $\mathrm{CO}_{2}$ to enter the sub-stomatal chamber.

This larger volume of $\mathrm{CO}_{2}$ enabled higher rates of photosynthesis, at least up to a certain limit, which in the case of this study appeared to be when there was an excess of irrigation, with ETcloc greater than 100\%. The possible 'flooding' effect may have caused the stomata to close and reduced photosynthesis (Taiz et al., 2017), and may have maintained a high concentration of the gas in the sub-stomatal chamber, since its assimilation was compromised by the reduction in the photosynthetic rate.

No difference was found in leaf temperature between plants grown in soil covered or not with carnauba straw (Figure 7f), regardless of the ETc depth used.

A difference in yield was seen between the treatments under evaluation, with the irrigation depths combined with the ground cover of carnauba straw being noteworthy, as these always 
showed greater productivity compared to the treatments with no ground cover but with the same level of water replacement (Figure 8).

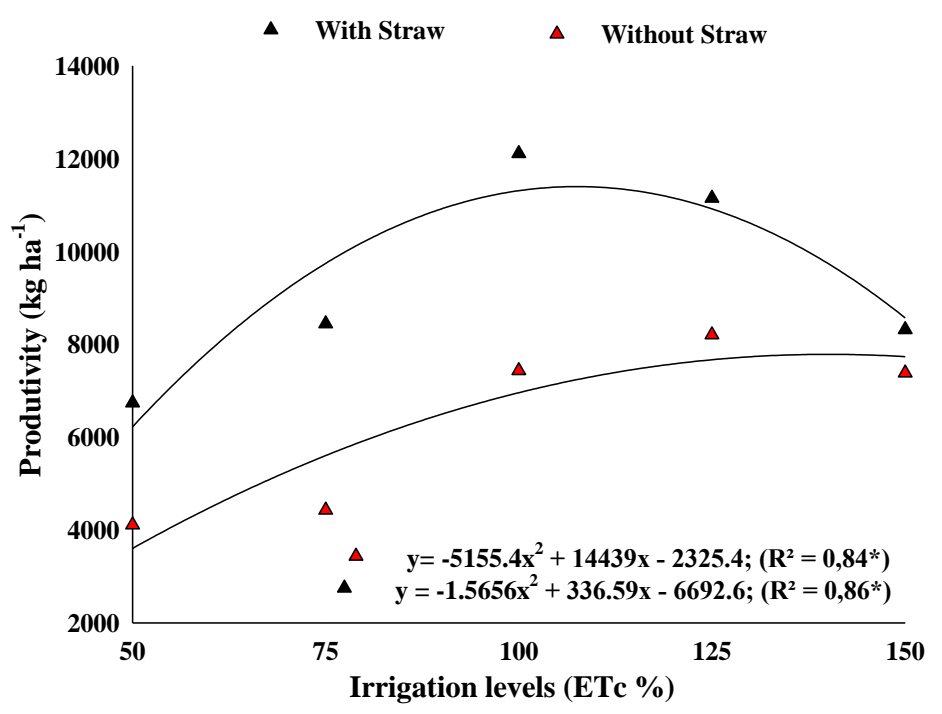

Fig. 8. Productivity in the 'red' cherry tomato grown in soil with ground cover (Carnauba straw) and with no ground cover, with both submitted to different levels of irrigation

Other researchers working with the cherry tomato obtained different yields. Preczenhak et al. (2014), working with the 'Sweet Grape' cultivar, obtained a yield of $2.08 \mathrm{~kg}$ plant-1, a higher result than that seen in this research. Menezes et al. (2012) achieved a production of $544.8 \mathrm{~g}$ plant-1 from the CLN1561A accession, and $452.35 \mathrm{~g} \mathrm{plant}^{-1}$ from the Carolina cultivar, i.e. lower than the greatest yields per plant seen in this study.

Through derivation of the equation that modelled the results of this variable, the ETcloc replacement rate that provided maximum productivity $\left(11,398.36 \mathrm{~kg} \mathrm{ha}^{-1}\right)$ was $107.5 \%$, i.e. 226.85 $\mathrm{L} \mathrm{plant}^{-1}$ cycle $^{-1}$. When the soil had no ground cover, the maximum productivity was $7,784.6 \mathrm{~kg} \mathrm{ha}^{-1}$, acquired at a water content of $296 \mathrm{~L}$ plant-1 cycle ${ }^{-1}$, and achieved at the maximum water depth of $140 \%$ ETcloc.

From the data, it can be seen that it is possible to obtain the same productivity as the soil with no ground cover $\left(7,778.86 \mathrm{~kg} \mathrm{ha}^{-1}\right)$, using carnauba straw with a water depth of $59.5 \%$ ETcloc, generating a saving of $3,400 \mathrm{~m}^{3}$ water cycle ${ }^{-1} \mathrm{ha}^{-1}$; it is also possible to increase the area cultivated with tomatoes without necessarily requiring greater water availability.

A different response was found by Harmanto et al. (2004) for a water replacement of $75 \%$ ETc, estimated by the Penman-Monteith equation, which gave the best result for the tomato grown in a greenhouse.

According to Silva et al. (2013), the tomato is sensitive to water stress, and when irrigated with depths of less than $100 \%$ Etc, low productivity may result due to the lack of water, affecting the photosynthetic rate and, consequently, the productivity of the species.

Relating the physiological characteristics studied so far to the productivity achieved, a direct 
relationship between them can clearly be seen, with the greatest productivity obtained in those treatments that presented the best results for stomatal conductance, photosynthetic rate and instantaneous carboxylation efficiency.

According to Bandeira et al. (2011), for vegetables in general, development is influenced by soil moisture, water deficit being the most limiting factor to high productivity and good quality fruit; excess water in the soil can also cause serious damage, as seen in this study at water depths of $125 \%$ ETcloc or more. Therefore, replacing water in the soil through irrigation, in the right amount and at the right time, is a determining factor for success in the production of the cherry tomato.

Water use efficiency (WUE) is a parameter related to the total harvest yield per unit of water used (Silva et al., 2013). Based on the irrigation management adopted in this experiment, a WUE of the order of $3.06 \mathrm{~kg} \mathrm{~m}^{-3}$ was seen when using carnauba straw and an irrigation depth of $205 \mathrm{~mm}$; whereas in the soil with no ground cover, the greatest acquired efficiency, of 1.95 $\mathrm{kg} \mathrm{m}^{-3}$, was seen at an irrigation depth of $211 \mathrm{~mm}$, showing a large difference between the plants grown with or without a ground cover of carnauba straw (Figure 9).

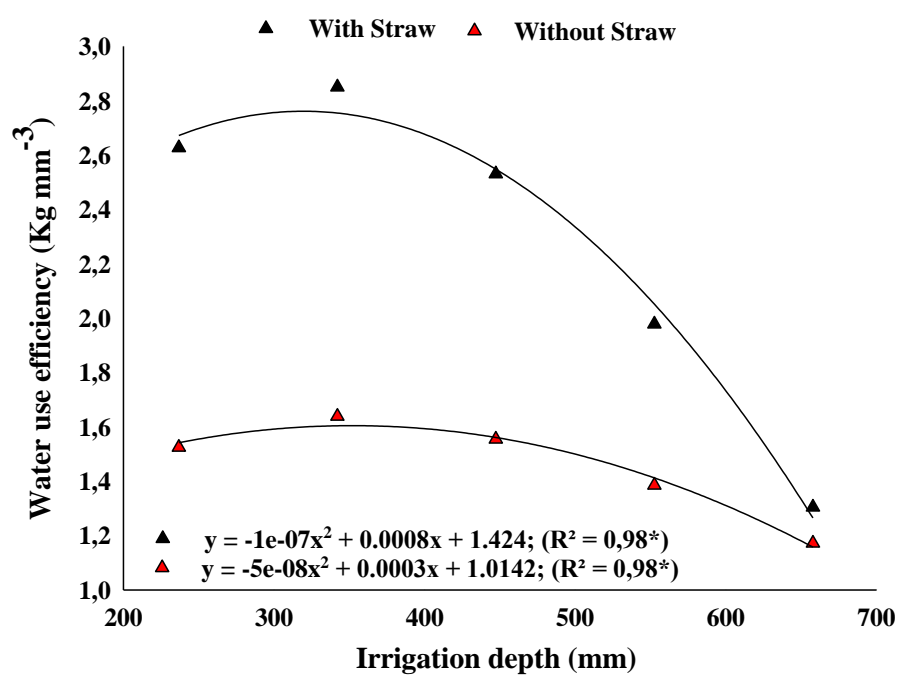

Fig. 9. Water use efficiency in the 'red' cherry tomato grown in soil with ground cover (Carnauba straw) and with no ground cover, with both submitted to different levels of irrigation

Considering that the water depth applied in irrigation constitutes an important parameter in calculating the efficiency indices of both types of soil, the benefit of covering the soil with carnauba straw in relation to the soil with no cover is confirmed for the soil and climate conditions of the region.

When comparing the irrigation depth, a water use efficiency of 3.19, 2.67, 2.87, 2.11 and 1.31 $\mathrm{kg} \mathrm{m}^{-3}$ was found in the covered soil for an ETcloc replacement rate of 50, 75, 100, 125 and $150 \%$ respectively; while for the soil with no cover the water use efficiency was $1.95,1.40$, $1.76,1.55$ and $1.16 \mathrm{~kg} \mathrm{~m}^{-3}$. 
Other studies have also demonstrated water use efficiency in the tomato (Yang et al., 2017), and show the importance of the careful use of irrigation management, as well as the need to determine the correct level of water for the plants that would allow better use of the water resources and give greater economic return (Oliveira Neto et al., 2011; Carvalho et al., 2011).

\section{Conclusion}

The results show that the use of carnauba straw together with an irrigation depth of $100 \%$ Etcloc results in greater water use efficiency in cultivating the 'red' cherry tomato under the conditions of recurrent water scarcity in the semi-arid region.

\section{References}

Abdel-Razzak, H., Ibrahim, A., Wahb-Allah, M., \& Alsadon, A. (2013). Response of Cherry Tomato (Solanum lycopersicum var. Cerasiforme) to Pruning Systems and Irrigation Rates under Greenhouse Conditions Asian J. Crop Sci., 5, 275-285. https://doi.org/10.3923/ajcs.2013.275.285

Abdel-Razzak, H., Wahb-Allah, M., Ibrahim, A., Alenazi, M., \& Alsadon, A. (2016). Response of Cherry Tomato to Irrigation Levels and Fruit Pruning under Greenhouse Conditions. J. Agr. Sci. Tech., 18, 1091-1103. https://doi.org/10.3923/ajcs.2013.275.285

Albuquerque Neto, A. A. R., \& Peil, R. M. N. (2012). Produtividade biológica de genótipos de tomateiro em sistema hidropônico no outono/inverno. Hortic Bras., 30, 613-619. https://doi.org/10.1590/S0102-05362012000400009

Alian, A., Altman, A., \& Heuer, B. (2000). Genotypic difference in salinity and water stress tolerance of fresh market tomato cultivars. Plant Science, 152, 59-65. https://doi.org/10.1016/S0168-9452(99)00220-4

Alvarenga, M. A. R., \& Coelho, F. S. (2013). Valor nutricional. In: Alvarenga MAR (2ed) Tomate: produção em campo, em casa de vegetação e hidroponia, cap. 2. Revista e ampliação. Lavras, MG: Editora Universitária de Lavras, pp. 23-30.

Bandeira, G. R., Pinto, H., Magalhães, P. S., Aragão, C. A., Queiroz, S., Souza, E. R., \& Seido, S. L. (2011). Manejo de irrigação para cultivo de alface em ambiente protegido. Hortic Bras., 29, 237-241. https://doi.org/10.1590/S0102-05362011000200018

Beckles, D. M. (2012). Factors Affecting the Postharvest Soluble Solids and Sugar Content of Tomato (Solanum lycopersicum L.) Fruit. Postharvest Biol. Technol., 63, 129-140. https://doi.org/10.1016/j.postharvbio.2011.05.016

Bernardo, S., Soares, A. A., \& Mantovani, E. C. (2009). Manual de irrigação (8ed) Viçosa, Minas Gerais, pp625.

Cafe-Filho, A. C., Lopes, C. A., \& Rossato, M. (2019). Management of plant disease epidemics with irrigation practices. In: Ondrasek, Gabrijel (Ed.), Irrig Agroec. Intech Open, pp. 123-141. https://doi.org/10.5772/intechopen.78253

Carvalho, D. F., Neto, D. H. O., Ribeiro, R. L. D., Guerra, J. G. M., \& Rouws, J. R. C. (2011). Manejo da irrigação associada a coberturas mortas vegetais no cultivo orgânico da beterraba. Eng Agrí., 31, 269-277. https://doi.org/10.1590/S0100-69162011000200007 
Cordeiro, G. G. (2001) Qualidade de Água para Fins de Irrigação (Conceitos básicos e práticos). (ed) Embrapa, Petrolina, PE, pp.32. https://doi.org/bitstream/doc/151757/1/SDC16

Daniel, A. C., Lage, W. A., Marouelli, B., Adalberto, C., \& Cafe-Filho, A. C. (2019). Management of powdery mildew and behaviour of late blight under different irrigation configurations in organic tomato. Crop Protec., 125, 104886. https://doi.org/10.1016/j.cropro.2019.104886

Doorenbos, J., \& Kassam, A. H. (1994). Efeito da água no rendimento das culturas. Estudos da FAO: Irrigação e Drenagem. Campina Grande, pp.306.

Ferreira, D. F. (2011). SISVAR - Sistemas de análises estatísticas. Versão 5.3. Lavras: Departamento de Ciências Exatas, UFLA.

Goto, R., \& Tivelli, S. W. (1998). Produção de hortaliças em ambiente protegido: condições subtropicais. São Paulo: Fundações Editoras da UNESP. pp309.

Harmanto, V. M., Salokhe, B. M. S., \& Tantau, H. J. (2004). Water requirement of drip irrigated tomatoes grown in greenhouse in tropical environment. Agric Water Manag., 71, 225-242. https://doi.org/10.1016/j.agwat.2004.09.003

Lima, M. E., Carvalho, D. F., Souza, A. P., Guerra, J. G. M., \& Ribeiro, R. L. D. (2009) Desempenho da alface em cultivo orgânico com e sem cobertura morta e diferentes laminas de água. Cien agrotec, 33, 1503-1510. https://doi.org/10.1590/S1413-70542009000600007

Lima, M. E., Carvalho, D. F., Souza, A. P., Rocha, H. S., \& Guerra, J. G. M. (2012) Desempenho do cultivo da berinjela em plantio direto submetida a diferentes lâminas de irrigação. Bras Ang Agri Amb, 6, 604-610. https://doi.org/10.1590/S1415-43662012000600003

Loos, R. A., Caliman, F. R. B., \& Silva, D. J. H. (2009). Enxertia, produção e qualidade de tomateiro cultivado em ambiente protegido. Cien Rural., 39, 232-235. https://doi.org/10.1590/S0103-84782009000100037

Maas, E. V., \& Hoffman, G. J. (1977). Crop salt tolerance - Current Assessment Asce J Irrig Drain Div., 103, 115-134. https://doi.org/CEDBsearch/record.jsp?dockey=0007414

Macêdo, L. S., \& Alvarenga, M. A. R. (2005). Efeito de lâminas de água e fertirrigação potássica sobre o crescimento, produção e qualidade de frutos de tomateiro em ambiente protegido. Cien agrotec., 29, 296-304. https://doi.org/10.1590/S1413-70542005000200005

Manzoni, S., Vico, G., Katul, G., \& Porporato, A. (2013). Biological Constraints on water transport in the soil-plant-atmosphere. Adv in Water Resour., 51, 292-304. https://doi.org/10.1016/j.advwatres.2012.03.016

Marouelli, W. A., Santana, R. R., Silva, W. L. C., Moretti, C. L., \& Vilela, N. J. (2003). Avaliação técnica e econômica do espaçamento de gotejadores em tomateiro para processamento cultivado em fileiras simples e duplas. Hortic Brasi., 21, 202-206. https://doi.org/10.1590/S0102-05362003000200016

Mattar, M. A., Zin El-Abedin, T. K., Alazba, A. A., \& Al-Ghobari, H. M. (2020). Soil water status and growth of tomato with partial root-zone drying and deficit drip irrigation techniques. Irrig Sci., 38, 163-176. https://doi.org/10.1007/s00271-019-00658-y 
Menezes, J. B. C., Costa, C. A., Sampaio, R. A., Catão, H. C. M., Guilherme, D. O., \& Martinez, R. A. S. (2012) Fruit production and classification of four cherry tomato genotypes under an organic cropping system. Ides., 30, 29-35. https://doi.org/10.4067/S0718-34292012000300004

Mesquita, J. B. R., Azevedo, B. M., Campelo, A. R., Vieira, C. N., \& Viana, T. V. A. (2013) Crescimento E produtividade da cultura do gergelim (Sesamum indicum L.) sob diferentes níveis de irrigação, irriga, 8, 364-375. https://doi.org/10.15809/irriga.2013v18n2p364

Monte, J. A., Pacheco, A. S., Carvalho, D. F., \& Pimentel, C. (2009). Influência do turno de rega no crescimento e produção do tomateiro no verão em Seropédica. Hortic Bras., 27, 222-227. https://doi.org/10.1590/S0102-05362009000200018

Mulumba, L. N., \& Lal, R. (2008). Mulching effects on selected soil physical properties. Soil Tillag Resear., 98, 106-111. https://doi.org/10.1016/j.still.2007.10.011

Oliveira Neto, D. H., Carvalho, D. F., Silva, L. D. B., Guerra, J. G. M., \& Ceddia, M. B. (2011). Evapotranspiração e coeficientes de cultivo da beterraba orgânica sob cobertura morta de leguminosa e gramínea. Hortic Bras., 29, 330-334. https://doi.org/10.1590/S010205362011000300012

Pék, Z., Szuvandzsiev, P., Daood, H., Neményi, A., \& Helyes, L. (2014). Effect of irrigation on yield parameters and antioxidant profiles of processing cherry tomato. Central Europ Jour Biol., 9, 383-395. https://doi.org/10.2478/s11535-013-0279-5

Pék, Z., Szuvandzsiev, P., Neményi, A., \& Helyes, L. (2015). Effect of season and irrigation on yield parameters and soluble solids content of processing cherry tomato. Acta Hortic., 1081, 197-202. https://doi.org/10.17660/ActaHortic.2015.1081.24

Pereira, J. W. L., Melo Filho, P. A., Albuquerque, M. B., Nogueira, R. J. M. C., \& Santos, R. C. (2012). Mudanças bioquímicas em genótipos de amendoim submetidos a déficit hídrico $\begin{array}{lllll}\text { moderado. } \quad \text { Rev } & \text { Ciênc } & \text { 76ron., } & \text { 43, }\end{array}$ https://doi.org/10.1590/S180666902012000400019

Perveen, R., Suleria, H. A. R., Anjum, F. M. Butt, M. S. Pasha, I., \& Ahmad, S. (2015). Tomato (Solanum lycopersicum) carotenoids and lycopenes chemistry: metabolism, absorption, nutrition, and allied health claims. A Compreh Rev, Crit Rev in Food Scie and Nutrit., 55, 919-929. https://doi.org/10.1590/0103-9016-2015-0427

Picanço, M., Leite, G. L. D., Guedes, R. N. C., \& Silva, E. A. (1998). Yield loss in trellised tomato affected by insecticidal sprays end plant spacing. Crop Protec., 17, 447-452. https://doi.org/10.1016/S0261-2194(98)00040-4

Plaza-Bonilla, D., Jean-Marie, N., Raffaillaca, D., \& Justesa, E. (2015). Cover crops mitigate nitrate leaching in cropping systems including grain legumes: Field evidence and model simulations. Agricul Ecosy Envir., 212, 1-12. https://doi.org/10.1016/j.agee.2015.06.014

Preczenhak, A. P., Resende, J. T. V., Chagas, R. R., Silva, P. R., Schwarz, K., \& Morales, R. G. F. (2014). Caracterização agronômica de genótipos de minitomate. Hortic Bras., 32, 348-356. https://doi.org/10.1590/S0102-053620140003000018

Sá, N. S. A., Pereira, G. M., Alvarenga, M. A. R., Mattioli, W., \& Carvalho, J. A. (2005). 
Behavior of tomato crop under diferente soil water tensions in a greenhouse (2005). Rev bras eng agríc ambient, 9, 341-347. https://doi.org/10.1590/S141543662005000300008

Santana, M. J., Vieira, T. A., \& Barreto, A. C. (2009). Efeito dos níveis de reposição de água no solo na produtividade do tomateiro. Hortic Bras., 27, 1378-1384. https://doi.org/1020093/A1965T292800000/003

Schwarz, K., Resende, J. T. V., Preczenhak, A. P., Paula, J. T., Faria, M. V., \& Dias, D. M. (2013). Desempenho agronômico e qualidade físico-química de híbridos de tomateiro em cultivo Hasteiro. Hortic Bras., https://doi.org/10.1590/S010205362013000300011

Silva, A. C., Costa, C. A., Sampaio, R. A., \& Martins, E. R. (2011). Avaliação de linhagens de tomate cereja tolerantes ao calor sob sistema orgânico de produção. Rev Caatin., 24, 33-40. https://doi.org/6842-1-10-20110704

Silva, J. M., Ferreira, R. S., Melo, A. S., Suassuna, J. F., Dutra, A. F., \& Gomes, J. P. (2013). Cultivo do tomateiro em ambiente protegido sob diferentes taxas de reposição da evapotranspiração. Rev bras eng agríc ambiente. 17, 40-46. https://doi.org/10.1590/S141543662013000100006

Soares Júnior, A. P., \& Farias, L. M. (2012). Efeito do licopeno do tomate na prevenção do câncer de próstata. Rev Interdiscip NOVAFAPI, Teresina, 5, 50-54. https://doi.org_3A1586370701094

Taiz, L., Zeiger, E., Moller, M. I., \& Murphy, A. (2017). Fisiologia e Desenvolvimento Vegetal (6ed) Porto Alegre, Artmed editora, 858p.

Wang, R. S., Kang, Y. H., Wan, S. Q., Hu, W., Liu, S. P., \& Liu, S. H. (2011a). Salt distribution and the growth of cotton under different drip irrigation regimes in a saline area. Agric Water Manag., 100, 58-69. https://doi.org/10.1016/j.agwat.2011.08.005

Xu L., Yu J., Han L., \& Huang B. (2013). Photosynthetic enzyme activities and gene expression associated with drought tolerance and post-drought recovery in Kentucky bluegrass. Environ Exper Botany, 89, 28-35. https://doi.org/10.1016/j.envexpbot.2012.12.001

Yang, H., Du, T., Qiu, R, Chen J., Wang, F., Li, Y., ... Kang, S. (2017). Improved water use efficiency and fruit quality of greenhouse crops under regulated deficit irrigation in northwest China. Agric. Water Manage, 179, 193-204. https://doi.org/10.1016/j.agwat.2016.05.029

Zhou, Q., \& Yu, B. (2010). Changes in content of free, conjugated and bound polyamines and osmotic adjustment in adaptation of vetiver grass to water deficit. Plant Physiology and Biochemistry, 48, 417-425. https://doi.org/10.1016/j.plaphy.2010.03.003

\section{Copyright Disclaimer}

Copyright for this article is retained by the author(s), with first publication rights granted to the journal.

This is an open-access article distributed under the terms and conditions of the Creative Commons Attribution license (http://creativecommons.org/licenses/by/4.0/). 